\title{
手の悪性腫瘍と機能温存の苦悩
}

\author{
産業医科大学整形外科 \\ 萱 岡 道 泰・鈴 木 勝 己 \\ 酒 井 昭 典・坂 井一夫
}

\section{Surgical Procedure and Postoperative Function in Treatment of Malignant Bone and Soft Tissue Tumors of the Hand \\ by}

\author{
Michiyasu Kayaoka, Katsumi Suzuki, Akinori Sakai and Kzuo Sakai \\ Department of Orthopaedic Surgery, School of Medicine University \\ of Occupational and Environmental Health, Japan
}

We treated 6 cases of malignant bone and soft tissue tumors of the hand during the 15 year period, 1978-1993.

They were histologically diagnosed as infantile fibrosarcoma, malignant lymphoma, chondrosarcoma and rhabdomyosarcoma (3 cases) respectively.

Biopsy was performed in one case, wide excision and reconstruction in two cases, and ray amputation in three cases.

Recently radiation and/or chemotherapy have been used as an adjunctive method before and/or after surgery.

In this paper, we present problems concerning surgical procedures and residual postoperative function, and discuss the appropriate surgical margin for excision of malignant hand tumors.

Key words : hand (手), malignant bone tumor (覀性骨腫瘍), malignant soft tissue tumor (悪性軟部 腫瘍), surgical margin (外科的切除縁), reconstruction (機能再建)

\section{は じめに}

手の悪性腫瘍に対する観血的治療は, 根治的切除と 機能温存の両立に苦慮することが多い. 今回我々は, 1978 年以降, 当科で治療した 6 例の中で指温存し広 範囲切除を行った線維肉腫と横紋筋肉腫の 2 例を中心 に臨床経験を報告する。

症例の概要は Table 1 のごとくである.

症例

症例 1 : 現在, 6 歳 6 力月の女児. 2 歳 3 力月時, 右母示指間背部の腫脹に気づき, 近医を受診. $\mathrm{X}$ 線 上, 右第 2 中手骨全体に蜂窩状陰影, 骨膜反応があり,
骨腫瘍を疑われ当科を紹介受診した。骨シンチ・術前 血管造影で異常所見はみとめられなかった. 生検では, 筋膜に不均一な紋様状の不整があり, 腫瘍組織は灰白 色の軟性ゼリ一状，中手骨表面は顆粒状に凹凸不整で 脆弱であった，髄内にも同様の組織が充満していた。 迅速病理組織診断では, 良・悪性の診断ができず可及 的に切除した. 生検後右手背の腫脹は増大傾向があり, CTでは，第 3 中手骨まで腫瘍が巻き込んでいた (Fig. 1). 2 力月後, 第 $2 \cdot 3$ 中手骨, 手内筋を含めて の広範囲切除を行い, 骨セメントをスペーサーとして 用いた (Fig. 2). 病理組織診断は乳幼児型線維肉腫 であった. 7 カ月後, 感染がおこったため除去し, シ リコン インプラントを挿入した. 挿入後 4 カ月より 


\begin{tabular}{|c|c|c|c|c|c|c|}
\hline Case & $\begin{array}{l}\text { Histology } \\
(\text { Age, Sex })\end{array}$ & $\begin{array}{l}\text { Complaint } \\
\text { \& Region }\end{array}$ & Stage & $\begin{array}{l}\text { Surgical } \\
\text { Treatment }\end{array}$ & $\begin{array}{l}\text { Conbined } \\
\text { Therapy }\end{array}$ & Prognosis \\
\hline 1 & $\begin{array}{c}\text { Infantile } \\
\text { fibrosarcoma } \\
(2, F)\end{array}$ & & I A & $\begin{array}{l}\text { Biopsy } \\
\text { REtRecon.: }\end{array}$ & $(-)$ & $\begin{array}{c}4 \text { y } 3 \mathrm{~m} . \\
\mathrm{CDF}\end{array}$ \\
\hline 2 & $\begin{array}{l}\text { Malignant } \\
\text { 1ymphoma } \\
(77, M)\end{array}$ & (A) & II A & ray Ampu. & $\begin{array}{l}\text { Rad. } \\
\text { +Chemo. }\end{array}$ & $\begin{array}{c}1 \mathrm{y} 5 \mathrm{~m} . \\
\text { DOD }\end{array}$ \\
\hline 3 & $\begin{array}{l}\text { Rhabdomyo- } \\
\text { sarcoma } \\
(12, F)\end{array}$ & 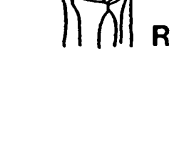 & III A & Biopsy & $\begin{array}{l}\text { Rad. } \\
\text { +Chemo. }\end{array}$ & $\begin{array}{l}7 \mathrm{~m} . \\
\text { DOD }\end{array}$ \\
\hline 4 & $\begin{array}{l}\text { Rhabdomyo- } \\
\text { sarcoma } \\
(7, F)\end{array}$ & & II $\mathrm{A}$ & $\begin{array}{l}\text { Biopsy } \\
\text { ray Ampu. }\end{array}$ & Chemo. & $\begin{array}{c}10 \mathrm{y} 5 \mathrm{~m} \\
\mathrm{CDF}\end{array}$ \\
\hline 5 & $\begin{array}{l}\text { Rhabdomyo- } \\
\text { sarcoma } \\
(42, F)\end{array}$ & 2 & II $\mathrm{A}$ & $\begin{array}{l}\text { ME-Recur. } \\
\text { WE + Becon. }\end{array}$ & Chemo. & $\begin{array}{r}3 m \\
N E D\end{array}$ \\
\hline 6 & $\begin{array}{l}\text { Chondro- } \\
\text { sarcoma } \\
(51, M)\end{array}$ & & I A & $\begin{array}{l}\text { ME } \\
\text { Ampu. }\end{array}$ & Chemo. & $\begin{array}{l}9 \text { y } 11 \mathrm{~m} \\
\mathrm{CDF}\end{array}$ \\
\hline
\end{tabular}

*ME : marginal excision.

Ampu. : amputation. WE; wide excision. Recon.;reconstruction, Recur.;recurrence,

Rad. ;radiation. Chemo.; chemotherapy.

CDF; continuous disease free. NED; no evidence of disease.

DOD:dead on disease,

示指基節骨が脱臼したが, 4 年 3 力月の現在, $C D F$ である (Fig. 3).

症例 $5: 42$ 歳の女性. $\mathrm{H} 4$ 年 11 月初旬, 左手母示 指間の腫脹に気づいた。次第に増大してきたため近医 を受診し， 2 度穿刺した後, marginal excision 施行 された。病理組織診断は胞巣型横紋筋肉腫であり, 同 部位に再度腫瘍がみられた為，12月中旬当科を紹介 受診した。入院時現症は, 左母示指間に径 $1.0 \mathrm{~cm}$ 程 度の腫瘍を触知, 境界は比較的明瞭で弾性軟, 可動性
と圧痛があった，X線では，骨破壊はみられなかっ た.ガリウムシンチでも異常集積像はみられなかった (Fig. 4). 超音波検查では径 $1.1 \times 0.9 \mathrm{~cm}$ の内部に hyperechoic な反射を伴う腫瘍が認められた．第一背 側骨間筋との境界が一部不整であり，母指内転筋に一 部接していたが，虫様筋とは接していなかった。 MRI ではガドリニウムで増強される水様成分の多い 腫瘍が認められた。血管造影では early venous filling を伴う hypervascularな腫瘍陰影がみられた 


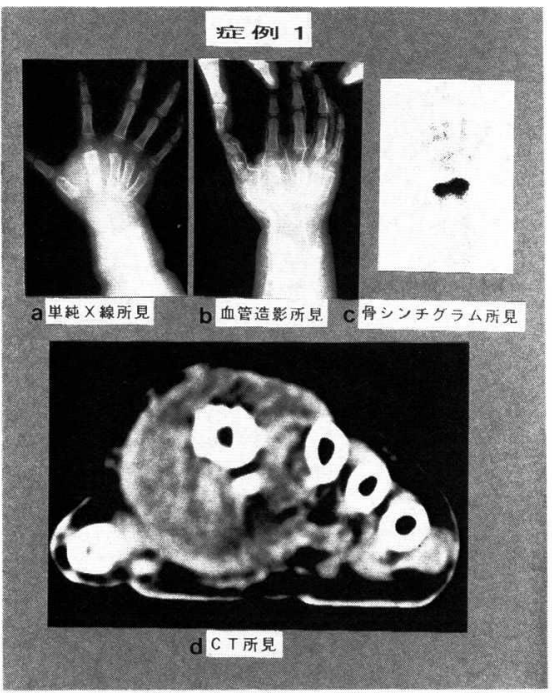

Fig. $1 \mathrm{a}$; 右第 2 中手骨全体に蜂窝状陰影, 骨膜反応あ り.

$\mathrm{b}, \mathrm{c}$; 異常所見なし.

$\mathrm{d} ;$ 第 3 中手骨まで腫瘍が巻き込んでいる.

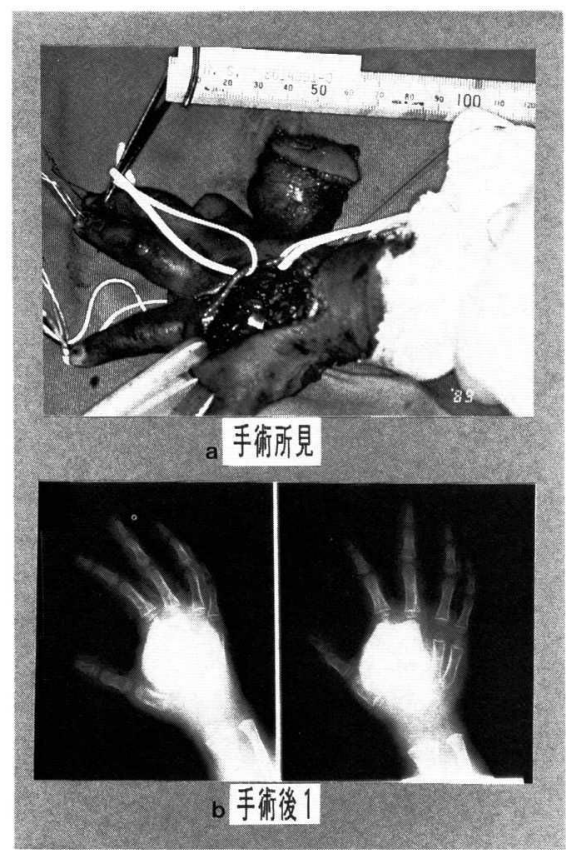

Fig. $2 \mathrm{a}$; 第 $2 \cdot 3$ 中手骨, 手内筋を含めて広範冊切除. b; スペーサーとして骨セメント使用.

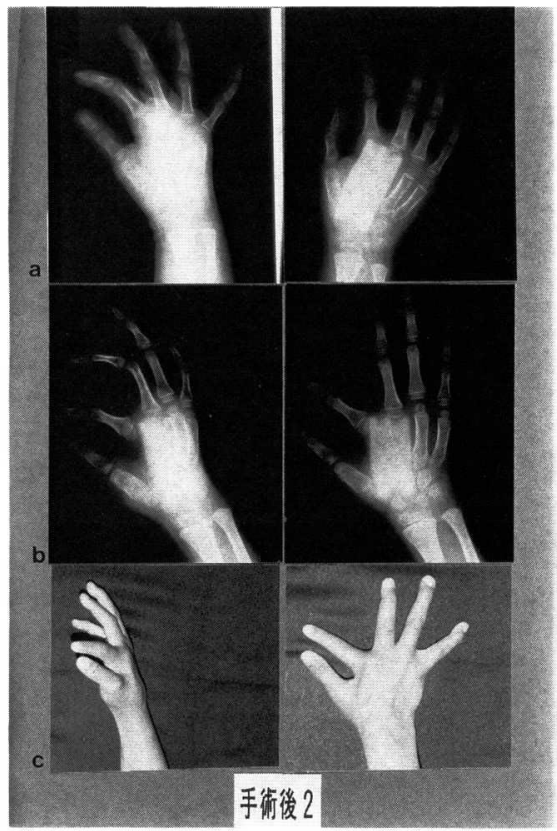

Fig. $3 \mathrm{a} ; 7$ カ月後, シリコン インプラント挿入. $b, c$; 挿入後 4 力月上り脱転傾向あり.

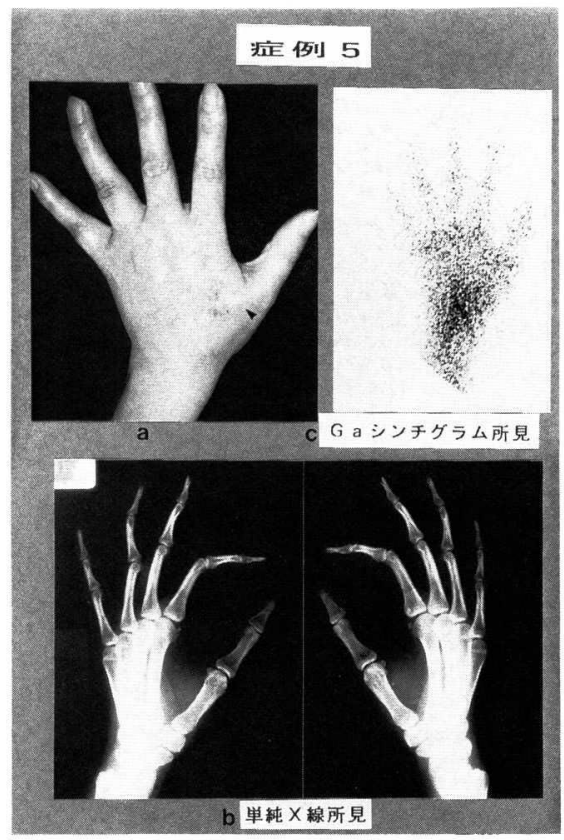

Fig. $4 \mathrm{a}$; 入院時, 左母示指間に径 $1.0 \mathrm{~cm}$ 程度の腫县を 触知.

b, c ; 異常所見なし. 


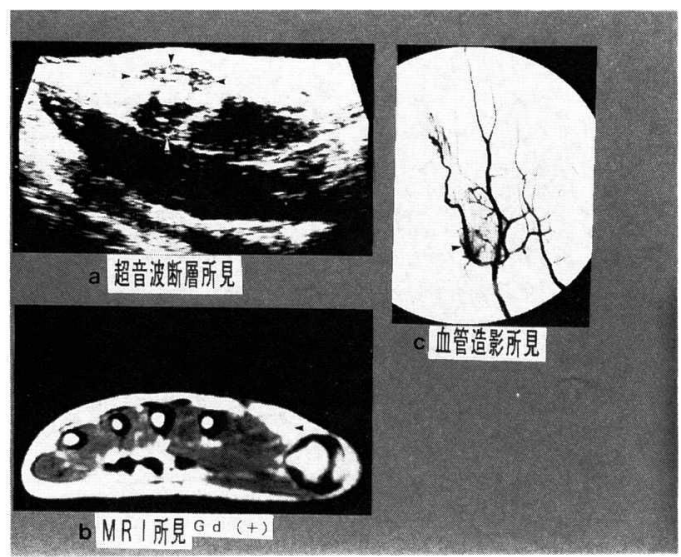

Fig. $5 \mathrm{a}$; 径 $1.1 \times 0.9 \mathrm{~cm}$ の内部に hyperechoic な反射を 伴う腫瑒あり、第一背側骨間筋との境界が一 部不整, 母指内転筋に一部接しているが, 虫 様筋とは接していない.

$\mathrm{b} ;$ ガドリニウムで増強される水様成分の多い腫 瘍。

c; early venous filling を伴う hypervascular な 腫瘍陰影。

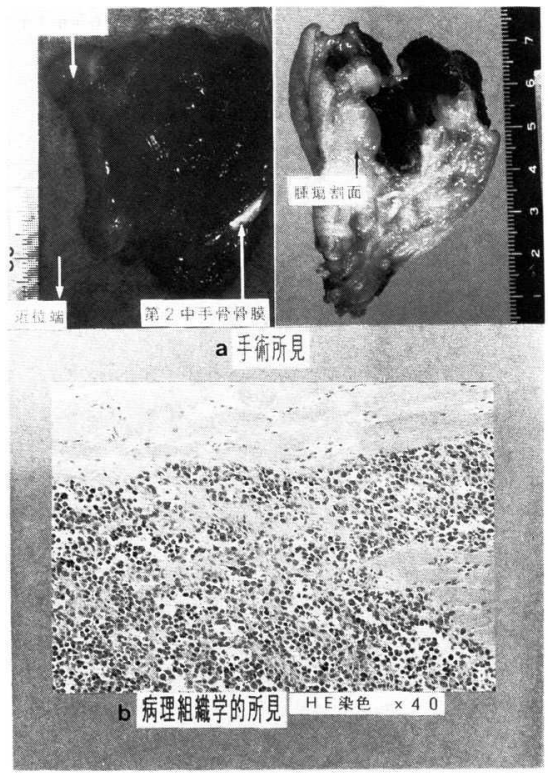

Fig. $6 \mathrm{a}$; 手術所見.

$\mathrm{b}$; 円形〜多形性の核および好酸性の広い細胞質 を有する腫瘍細胞。

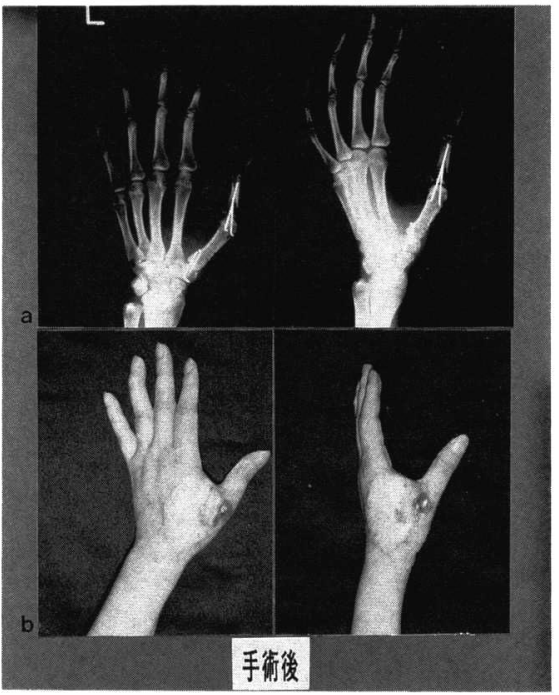

Fig. $7 \mathrm{a}, \mathrm{b}$;術後現在.

(Fig. 5). 手術所見は, 前回の ope scarを囲み, 腫 瘍周囲に近位は $2 \mathrm{~cm}$, その他は $1 \mathrm{~cm}$ の幅をつけ, 紡 錘状に皮切を加えた。尺側は第一背側骨間筋を第二中 手骨骨膜とともに剝離, 橈側は母指球筋, 長母指伸筋 を第一中手骨とともに切除し，近位端は CM 関節で 切除した。近位端は迅速病理にて腫瘍細胞がみられた ため, $1 \mathrm{~cm}$ 切除を追加しそれには腫瘍細胞はみられ なかった（Fig. 6). 第一中手骨はオートクレーブで 加熱処理後挿入し固定した。 久損部は有菱植皮した (Fig. 7). 術後, CYVADACT (VCT, ADR, CYC, $\mathrm{ACD})$ と $\mathrm{THP}+\mathrm{CDDP}(\mathrm{ADR}, \mathrm{CDDP})$ による補助的 化学療法を施行している.

考察

手の悪性腫瘍の特徵として，1) 早期発見，早期治療 が可能である．2)手の機能を障害された場合のハンディ キャップが大きい. 3) 手は解剖学的に前腕と連続し, 一つの compartment を形成しているので, 手の腫湟 を根治的に切除しようとすれば, 前腕からの切断が必 要となる４）術後の手の外観を考虑しなければならな い．5) 悪性腫瘍であることを患者に告知できないこと が多く, 根治的広範囲切除に患者が同意できない場合 がある。このような特徵を考慮して, 腫瘍の切除と手 指機能温存という相反する二つの面から治療を考えな ければならない. 
四肢原発悪性腫瘍の外科的治療を計画する上で,

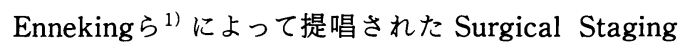
System は有用な指標となっているが, その Surgical procedure はそのまま手に応用するのは困難である。 また日整会骨軟部腫場委員会の切除縁評価基準にみら れる barrier の概念を用いても同様に困難である.

補助的化学療法が発達した ${ }^{2)}$ 現在では Surgical margin をどこに設定するかが問題となる.

Smithら ${ }^{3)}$ は手の悪性腫瘍に対し, 腫瘍のまわりに 2 から $3 \mathrm{~cm}$ の健常組織をつけた en bloc excisionを 第一とし, その切除面に腫瘍がみられれば,さらに $2 \mathrm{~cm}$ 切除範囲を広げ，その境界にも腫瘍がみられれ ば, 切断を考えるとしている.

手の悪性腫瘍に対する我々の方針としては, 手の悪 性腫瘍が疑われた場合, まず生検を行い, 組織診断よ り術前の放射線・化学療法の適応を考え, その後, な るべく多く barrier を含めて切除するか, 腫瘍から少 なくとも $2 \mathrm{~cm}$ 以上離して切除し, 経過観察するか, 機能再建をするか, 術後の放射線・化学療法の必要を 検討している.

症例 1 の乳幼児型線維肉腫については, 組織学的に 悪性度が高くても臨床的に予後良好なものが多く, 比 較的小さな wide marginの切除縁を確保すれば補助
的化学療法や放射線療法は不要で再発なく根治性が得 られるとされており ${ }^{4}$ 我々の場合も十分な治療がなさ れたと考える.スペーサーの脱転については同種骨移 植を考えている.

症例 5 の胞巣型横紋筋肉腫については, 切除縁が wide margin となり再発の危惧はあるが, 補助的化 学療法に期待するところが大きい.

$$
\text { ま と め }
$$

手の悪性腫瘍 6 例を経験し外科的切除縁について考 察し報告した。

\section{参 考 文 献}

1) Enneking, W. F., et al. : A system for the surgical staging of musculoskeletal sarcoma. Clin. Orthop., $153: 106-120,1980$.

2) Jaffe, N., et al. : Recent advances in the chemotherapy of metastatic osteogenic sarcoma. Cancer 30 : 1627-1631, 1972.

3) Smith, R. J. et al. : Surgery of the Musculoskeletal System, ed. R. I. Burton, Livingstone, Edinburgh, Vol. 4, 11th Ed., pp. 71-122, 1983.

4）谷川浩隆 他：乳幼児型線維肉腫の 2 例, 整形外科, 44 : 813-815, 1993. 